\section{PELATIHAN LAPORAN KEUANGAN PESANTREN DI PESANTREN DESA CIBITUNG TENGAH BOGOR}

\author{
Santi Susanti', Sri Zulaihati ${ }^{2}$ \\ 1,2) Universitas Negeri Jakarta \\ *Santi Susanti \\ Email : ssusanti@unj.ac.id
}

\begin{abstract}
Islamic Boarding School Accounting Reporting is important in Cibitung Tengan Village because in that village there are five Islamic boarding schools that still do not know the importance of financial reports. On the other hand, financial reports are an important element in the management of pesantren activities. We found various forms of partner problems in the preparation of pesantren financial reports, namely the pesantren's assets were still not recorded and there was also no financial reporting from the pesantren. The solutions offered to achieve this PKM goal are increasing the ability of pesantren financial staff and pesantren managers in managing pesantren funds and their financial reports, increasing managerial skills, increasing partners' knowledge of pesantren financial reports. So that it has the ability and skills that can be used to improve the quality of Islamic boarding school financial reporting and is expected to support increased accountability of Islamic boarding school financial reporting.

Keywords: Islamic boarding school financial reports, Accountability
\end{abstract}

\begin{abstract}
Abstrak
Pelaporan Akuntansi Pesantren menjadi penting di Desa Cibitung Tengan karena di desa tersebut terdapat lima pesantren yang masih belum mengetahui arti pentingnya laporan keuangan. Di sisi lain, laporan keuangan menjadi salah satu unsur penting dalam pengelolaan kegiatan pesantren. Kami menemukan berbagai bentuk permasalahan mitra dalam pembuatan laporan keuangan pesantren yaitu masih belum terekamnya asset pesantren dan juga tidak adanya pelaporan keuangan dari pesantren tersebut. Solusi yang ditawarkan untuk mencapai tujuan PKM ini adalah, peningkatan kemampuan staf keuangan pesantren dan para pengelola pesantren dalam mengelola dana pesantren serta laporan keuangannya, meningkatkan kemampuan manajerial, meningkatkan pengetahuan mitra terhadap laporan keuangan pesantren. Sehingga mempunyai kemampuan dan ketrampilan yang dapat digunakan untuk meningkatkan kualitas pelaporan keuangan pesantren dan diharapkan dapat menunjang peningkatan akuntanbilitas pelaporan keuangan pesantren.

Kata Kunci: laporan keuangan pesantren, Akuntabilitas
\end{abstract}


PELATIHAN LAPORAN KEUANGAN PESANTREN DI DESA CIBITUNG TENGAH BOGOR

Santi Susanti, Sri Zulaihati

Volume 1, No. 1, April 2021 hal. 20-27

DOI Artikel : 10.46306/jub.v1i1.5

\section{PENDAHULUAN}

Pesantren dengan berbagai potensi strategis yang dimilikinya, layak untuk menjadi lokomotif ekonomi syariah. Disisi lain, kemajuan perkembangan ekonomi syariah di Indonesia sangat memerlukan peran pesantren. Hal ini karena sampai saat ini pesantren masih menjadi institusi pendidikan Islam yang paling besar dan berpengaruh serta menjadi pusat pengkaderan ulama dan da'i yang legitimed di masyarakat. Apalagi sebenarnya produk- produk ekonomi syariah adalah kekayaan pesantren, yang digali dari figh muamalah dalam kitab kuning yang menjadi ciri khas pesantren. Seharusnya para santri lebih memahami ekonomi syariah daripada yang lain karena mereka sehari- hari bergelut dengan keilmuan syariah.

Percepatan pembangunan bangsa Indonesia memerlukan peran aktif dari seluruh elemen dalam sistem perekonomian, termasuk di dalamnya peran pesantren. Pengembangan pesantren secara khusus telah pula menjadi salah satu target pengembangan ekonomi Syariah mengingat perannya yang juga cukup strategis. Dukungan oleh berbagai faktor, pesantren memiliki potensi yang sangat besar untuk menjadi salah satu lokomotif pertumbuhan ekonomi Syariah dalam bentuk peningkatan produksi barang dan jasa serta mencetak sumber daya insani.

Salah satu karakteristik pesantren yang maju adalah kualitas pengelolaan yang baik dan mendukung terciptanya tata kelola yang baik. Kemampuan dalam memgelola proses pencatatan dan pelaporan transaksi keuangan merupakan hal yang paling mendasar dalam proses peningkatan tata kelola tersebut. Secara lebih luas, hal tersebut akan meningkatkan kepercayaan dari seluruh stakeholder yang secara jangka panjang diharapkan dapat mendukung pengembangan program pesantren. Program untuk mendorong adalah peningkatan tata kelola yang baik di lingkungan pesantren melalui tersedianya laporan keuangan yang memenuhi standar Akuntansi yang diterima secara luas oleh berbagai pihak, sehingga dapat meningkatkan eksistensi Lembaga pesantren sebagai Lembaga yang kredibel dan diakui.

Pada saat ini desa Cibitung Tengah Bogor aktivitas penduduknya adalah bertani. Desa Cibitung diapit oleh beberapa arus sungai sekaligus perbatasan desa. Di sebelah Barat sungai Ciampea dengan desa Ciampea Udik, di sebelah Timur dibatasi sungai Cinangneng dengan Desa Situ Daun.Sebelah Utara berbatasan dengan Desa Cinangneng sebelah Selatan dengan Desa Tapos II, sebelah Barat dengan Desa Ciampea Udik dan sebelah Timur dengan Desa Situ Daun.

Desa cibitung memiliki luas areal \pm I,047 ha. 176 ha. (36\%) untuk areal persawahan, 67I ha. (64 \%) berupa daratan terdiri atas 523 ha. berupa perkebunan dan sisanya I 48 ha. berupa perkampungan, tanah perkebunan, sarana sosial, jalan dan lain-lain. Desa Cibitung mempunyai Rw. (Rukun Warga) sebanyak 5 RW dari jumlah RT (Rukun Tetangga) sebanyak 22 Rt dengan kapasitas penduduk 7.389 jiwa. Penduduk Desa Cibitung sebahagian besar bermata pencaharian sebagai petani yaitu 1920 orang, Pegawai Negeri Sipil 240 orang, karyawan 252 orang, buruh 1440 orang. Untuk lebih jelasnya dapat dilihat dalam tabel berikut ini. Kepadatan penduduk yang dialami masyarakat desa Cibitung secara sosiologis dan antropologis memiliki dua keuntungan. Di satu sisi, secara potensial kemanusiawian akan menghasilkan beberapa cipta, karya dan karsa yang beraneka ragam tergantung pada sumber daya dari diri masing- 
PELATIHAN LAPORAN KEUANGAN PESANTREN DI DESA CIBITUNG TENGAH BOGOR

Santi Susanti, Sri Zulaihati

Volume 1, No. 1, April 2021 hal. 20-27

DOI Artikel : 10.46306/jub.v1i1.5

masing individu. Keaneka-ragaman potensi serta hasil dari proses eksplorasi akan membawa dampak yang besar bagi perkembangan sistem kemasyarakatan secara pesat. Di sisi lain, penduduk juga memiliki potensi besar terhadap terjadinya permasalahan, termasuk di dalam ketegangan sosial, kecemburuan sosial, politik, ekonomi dan pendidikan. Beberapa macam kecemburuan bisa muncul sebagai permasalahan, di antaranya adalah ras aman (secara luas).

Walaupun bagi masyarakat setempat rasa itu tidak pernah menjadi kendala, tetapi sering kali menjadi ancaman bagi msyarakat sekitar Desa Cibitung, sebagaimana pernah dituturkan beberapa warga setempat. Dilihat dari jumlah jenis mata pencaharian, ternyata masyarakat Desa Cibitung Tengah banyak bekerja sebagai petani, sementara tanah yang banyak mereka garap adalah areal ladang pesawahan. Pada sekitar paruh pertama tahun 2000 -an, kalangan tokoh masyarakat yang memiliki basic pendidikan formal (sekolah) pernah menyelenggarakan Sekolah Tinggi Agama Islam (STAI) dengan sumber pengajar dari kalangan kiyai dan sarjana yang terdapat di wilayah sekitar desa. Hal itu, telah memberikan sumbangan yang positif dalam pendidikan masyarakat terutama sangat membantu kalangan menengan ke bawah untuk mengenyam pendidikan lanjutan. Kehadiran lembaga pendidikan itu telah membawa kaum pelajar dari kalangan sekolah dan pesantren (santri) dapat mengikuti kegiatan pembelajaran itu. Selain memberikan fasilitas biaya yang murah, lokasi lembaga pendidikan tinggi itu dapat terjangkau masyarakat tanpa memakan biaya transportasi yang lebih tinggi. Melihat potensi yang ada di desa Cibitung Tengah Bogor maka kegiatan pengabdian Kepada Masyarakat melalui Pelatihan Laporan Keuangan Pesantren Di Desa Cibitung Tengah Bogor.

\section{METODE PENGABDIAN}

Dari uraian singkat khususnya tentang laporan Keuangan pesantren dapat dirinci permasalahan sebagai berikut:

\begin{tabular}{|c|l|l|}
\hline No & \multicolumn{1}{|c|}{ Aspek } & \multicolumn{1}{c|}{ Kondisi } \\
\hline I. & $\begin{array}{l}\text { Staf } \\
\text { Pesantren/SDM }\end{array}$ & $\begin{array}{l}\text { Terbatasnya kemampuan administrasi staf desa dan jumlah staf yang } \\
\text { juga sedikit }\end{array}$ \\
\hline 2. & Teknologi & Masih menggunakan proses manual dalam pengelolaan laporan \\
& & keuangan pesantren. \\
\hline 3. & Manajemen & $\begin{array}{l}\text { Belum adanya penerapan laporan keuangan pesantren yang } \\
\text { terintegrasi. }\end{array}$ \\
\hline
\end{tabular}

Table I : Uraian Masalah

Permasalahan di atas dapat digambarkan dalam bagan di bawah ini: 


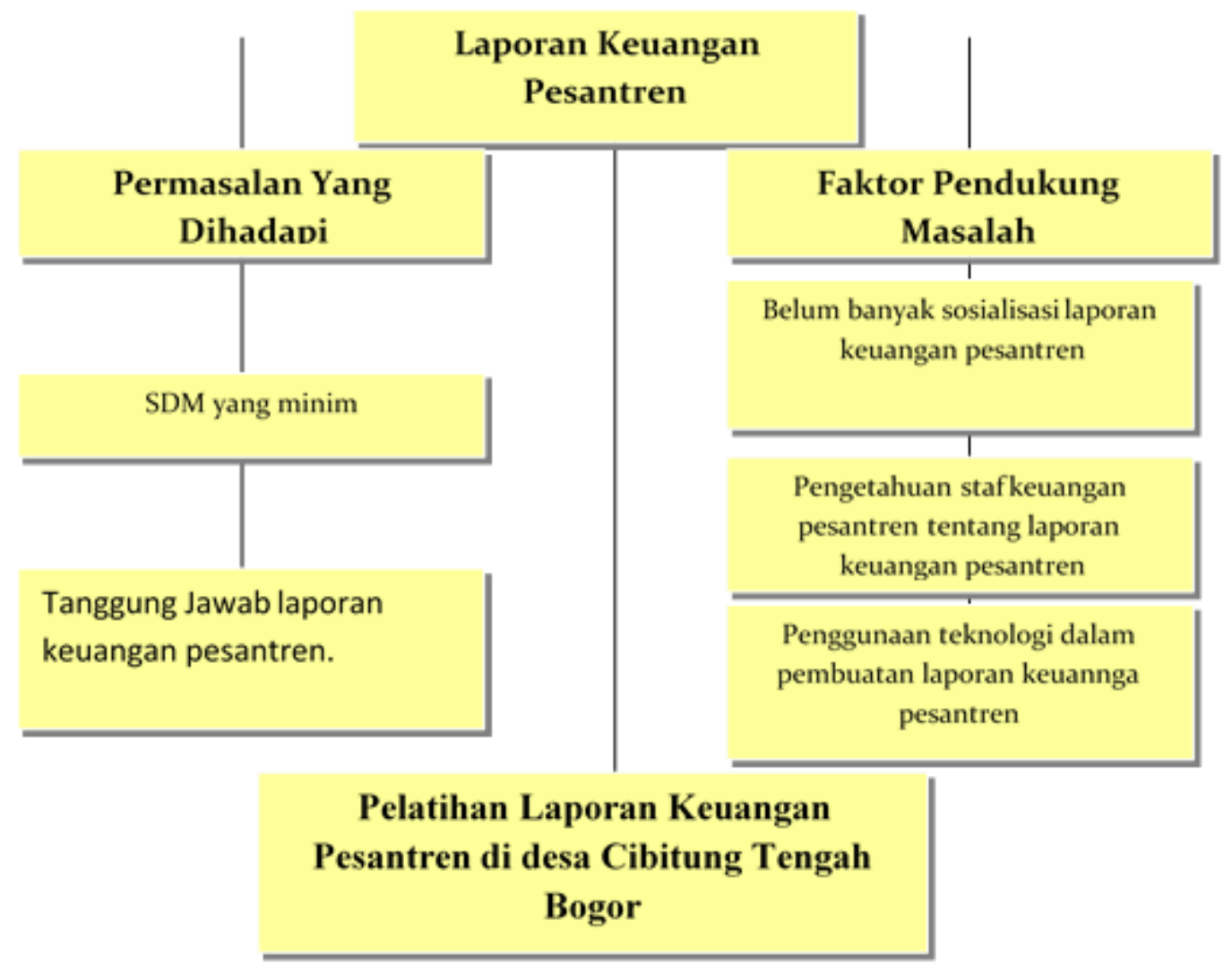

Gambar I: Alur Permasalahan yang dihadapi Pesantren

Kerangka atau tahapan dalam Pelatihan Laporan Keuangan UMKM di Desa Cibitung Tengah Bogor Jawa Barat adalah sebagai berikut:

\section{Analisis Kebutuhan}

Berdasarkan diskusi yang dilakukan oleh tim pengabdian masyarakat pada kegiatan Pelatihan Laporan Keuangan Pesantren di Desa Cibitung Tengah Bogor Jawa Barat terdapat ketimpangan sebagai berikut:

a. Kurangnya sumber atau materi pengetahuan staf keuangan pesantren tentang Laporan Keuangan Pesantren.

b. Masih rendahnya penggunaan aplikasi komputer dalam Laporan Keuangan Pesantren.

2. Rancangan Instruksional

Dalam menentukan rancangan instruksional ini perlu dipertimbangkan aspek-aspek berikut:

a. Isi materi program pelatihan yang relevan dengan kebutuhan mereka. Tim ini telah memetakan kebutuhan materi keseluruhan bagi staf keuangan pesantren di Desa Cibitung Tengah.

b. Latar belakang pendidikan Staf Keuangan yang mengelola pesantren.

c. Modul Laporan Keuangan Pesantren.

3. Tahap Pengembangan 
Dalam rangka pengembangan penyusunan modul Laporan Keuangan Pesantren, tim pengabdian masyarakat berupaya mengembangkan pelatihan ini baik dalam hal materi pelatihan Laporan Keuangan Pesantren, modul dan aplikasi komputer yang di sampaikan terkait dengan Laporan Keuangan Pesantren.

\section{PELAKSANAAN DAN PEMBAHASAN}

Bentuk Kegiatan yang dilakukan dengan tiga tahap secara online melalui Gmeet, yaitu:

I. Tahap satu:

Penyuluhan Tentang Pentingnya penyusunan laporan keuangan pesantren

Penyuluhan mengenai pentingnya pajak untuk Pengelola Pesantren di Desa Cibitung Tengah, Bogor. Adapun acara berupa penyuluhan mengenai laporan keuangan pesantren. Tahapan awal mengenai pelaporan keuangan pesantren bagi Pengelola Pesantren diharapkan Pengelola Pesantren lebih peduli terhadap penyusunan laporan keuangan pesantren. Penyusunan laporan keuangan pesantren bermanfaat untuk transparansi keuangan. Inti dari penyuluhan ini adalah membangun kesadaran warga bahwa penyusunan laporan keuangan pesantren berguna bagi kemajuan pesantren sebagai Lembaga pendidikan. Dalam tahap awal peserta diharapkan dapat mengidentifikasi asset yang dimiliki pesantren. Penyuluhan ini dilakukan untuk pengelola pesantren dan yayasan yang mengelola pesantren.

34 Bidang Usaha Milik Pesantren di berbagai sektor usaha:

-Retail

-Financing

-Jasa

-Industry Kreatif

-Agribisnis

-Property

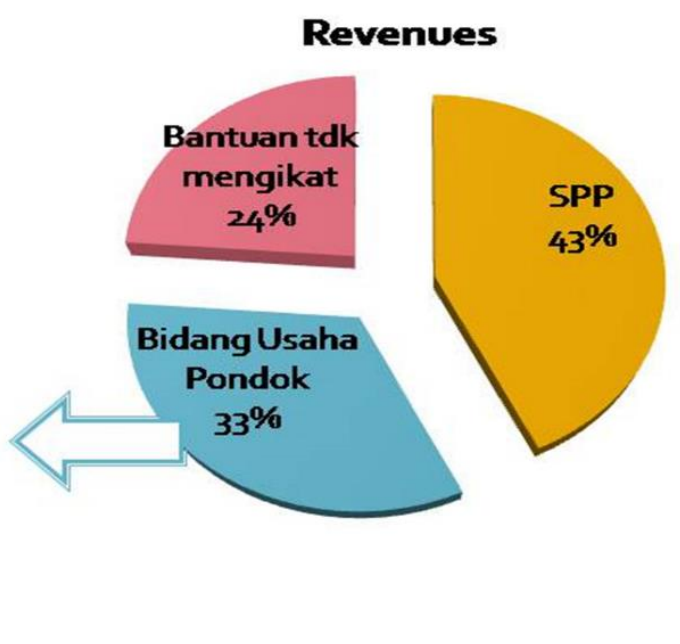

\section{Gambar 2: Prospek Pengembangan Aset Pesantren melalui Kewirausahaan Sosial}

2. Tahap dua:

Penyuluhan penyusunan laporan keuangan pesantren

Sesuai dengan tema pengabdian masyarakat yaitu "Pelatihan Laporan Keuangan Pesantren di Desa Cibitung Tengah Bogor Jawa Barat” menggarisbawahi bahwa peran laporan keuangan sangat penting. Dengan melakukan pelaporan keuangan pesantren yang rapi, maka akuntanbilitas dana masyarakat 
PELATIHAN LAPORAN KEUANGAN PESANTREN DI DESA CIBITUNG TENGAH BOGOR

Santi Susanti, Sri Zulaihati

Volume 1, No. 1, April 2021 hal. 20-27

DOI Artikel : 10.46306/jub.v1i1.5

yang dipakai dalam pengelolaan pesantren dapat dipertanggungjawabkan kepada para wali murid dan juga masyarakat secara umum. Diharapkan pengelola pesantren dapat Menyusun laporan keuangan pesantren sesuai dengan aturan yang berlaku.

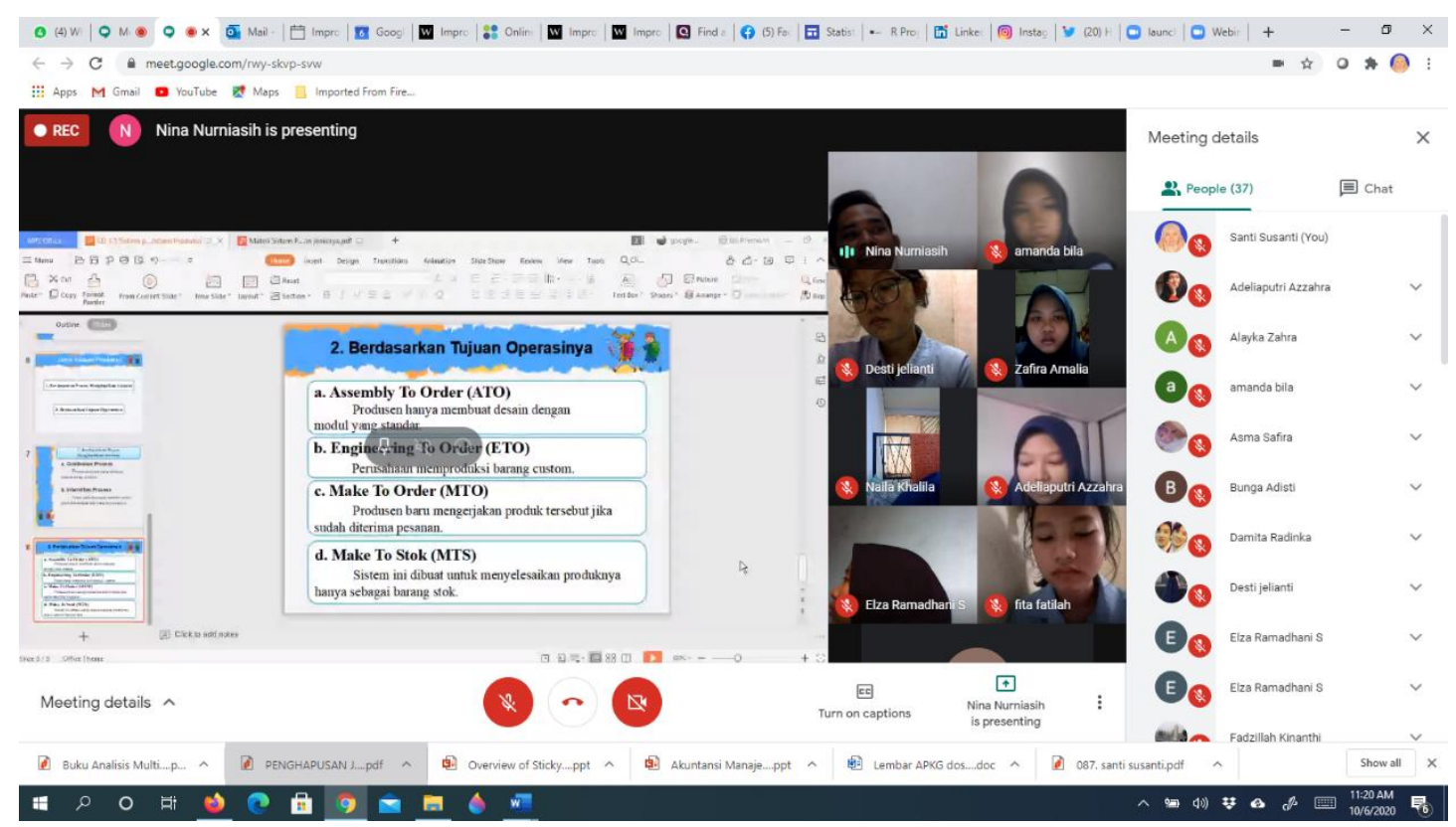

Gambar 3: Kegiatan Penyuluhan Laporan Keuangan Pesantren

3. Tahap tiga:

Pendampingan Penyusunan Laporan Keuangan Pesantren (berlangsung 6 bulan) Pendampingan Pelatihan Laporan Keuangan Pesantren di Desa Cibitung Tengah Bogor Jawa Barat setelah acara penyuluhan, memetakan aspek apa saja yang diperlukan dalam laporan keuangan pesantren, dan menyiapkan formulir yang diperlukan dalam administrasi pengelolaan keuangan di setiap kegiatan pesantren. Diharapkan setelah enam bulan berjalan dapat dilakukan pelaporan keuangan pesantren yang lebih efektif. Pendampingan laporan keuangan pesantren dilakukan oleh mahasiswa Universitas Negeri Jakarta.

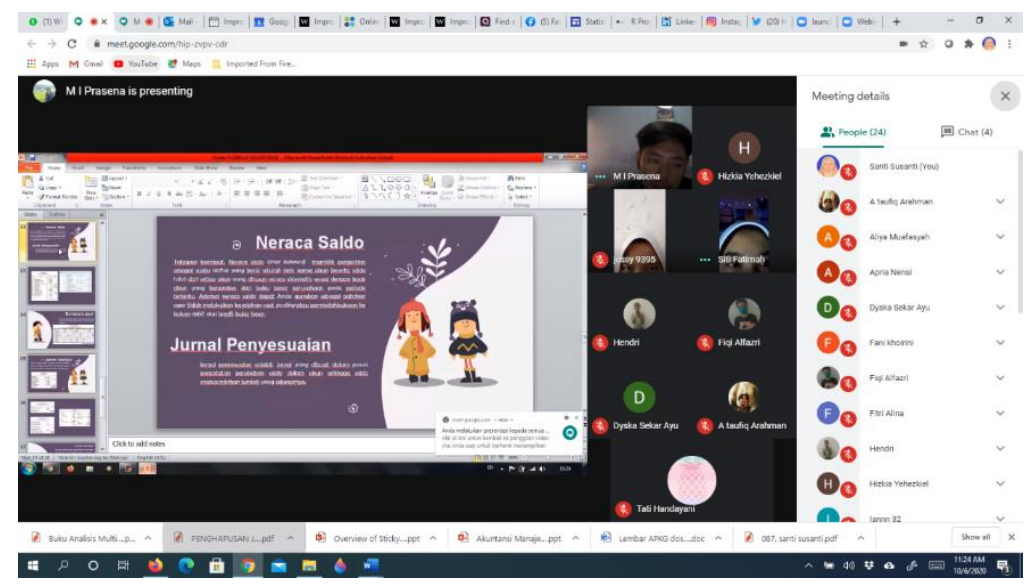

Gambar 4: Proses Pendampingan Penyusunan Laporan Keuangan oleh Mahasiswa 
Sasaran peserta terdiri dari 30 orang staf Pengelola Pesantren, di desa Cibitung tengah, Bogor, Jawabarat.

\section{Hasil Kegiatan}

Berdasarkan pengamatan dan obrolan santai dengan para peserta sosialisasi, maka didapatkan hasil sebagai berikut:

a. Menyadarkan masyarakat akan pentingnya kesadaran dalam penyunan laporan keuangan pesantren bagi pengelola pesantren.

b. Menjadikan kebiasaan penyusunan laporan keuangan pesantren.

c. Masyarakat memahami mekanisme penyusunan laporan keuangan pesantren.

\section{Faktor Pendukung dan Penghambat}

Kegiatan pengabdian masyarakat ini sangat didukung masyarakat serta pengelola pesantren di wilayah tersebut. Antusias warga pesantren pun tinggi untuk menyambut sosialisasi ini. Acara pun dibantu mahasiswa dari Fakultas Ekonomi Universitas Negeri Jakarta. Kebutuhan pesantren mendukung untuk penyusunan laporan keuangan pesantren yang lebih teratur. Faktor Penghambat ada beberapa pengelola pesantren belum menyadari pentingnya laporan keuangan pesantren. Dan masih banyak masyarakat yang belum mengerti mekanisme pelaporan keuangan pesantren, hingga perlu sosialisasi lebih jauh tentang penyusunan laporan keuangan pesantren.

\section{KESIMPULAN DAN SARAN}

Pengelola Pesantren di Desa Cibitung Tengah masih membutuhkan bimbingan dalam penyusunan laporan keuangan pesantren, memahami peran laproan keuangan dalam perkembangan pesantren sebagai Lembaga pendidikan. Disisi lain penyusunan laporan keuangan pesantren yang tertib dapat menunjang tingkat akuntanbilitas pesantren yang dikelola. Dengan adanya penyusunan laporan keuangan pesantren yang teratur, maka pengelola diharapkan dapat meningkatkan kesadarannyna dalam penyusunan laporan keuangan pesantren dan proses pengelolaan pesantren lebih baik lagi. Peran serta lembaga pendidikan dalam mengedukasi penyusunan laporan keuangan pesantren di tengah masyarakat masih sangat dibutuhkan. Selain itu pendampingan lembaga pendidikan juga penting untuk merealisasikan manfaat bagi lingkungan juga pemberdayaan ekonomi masyarakat. .

\section{DAFTAR PUSTAKA}

Gregory John Fealy, ljtihad Politik Ulama ; Sejarah NU 1952-1967 (Ulama and Politics in Indonesia a History of Nahdlatul Ulama 1952-1967), terj. Farid Wajidi dan Mulni Adelina Bachtar, Yogyakarta: LKiS, 2003.

Hasan Muarif Ambari, dalam Menemukan Peradaban; Jejak Arkeologis dan Historis Islam Indonesia, Jakarta: Logos, 2001. 
PELATIHAN LAPORAN KEUANGAN PESANTREN DI DESA CIBITUNG TENGAH BOGOR

Santi Susanti, Sri Zulaihati

Volume 1, No. 1, April 2021 hal. 20-27

DOI Artikel : 10.46306/jub.v1i1.5

Husni Rahim, Arah Baru Pendidikan Islam di Indonesia. Jakarta: Logos,200 I.

Mahmud Arif, dalam ,Tradisi Keilmuan dan Moralitas Pesantren', Jurnal Ilmu Pendidikan Islam. No. I Juli, 200 I.

Moeslim Abdurrahman, Islam Transformatif. Jakarta: Pustaka Firdaus, 1995.

Mukti Ali, ,Agama dan Perkembangan Ekonomi di Indonesia', dalam Muhammad Wahyuni Nafis et. al. (ed.), Kontekstualisasi Ajaran Islam. Jakarta: IPHI dan Yayasan Wakaf PARAMADINA, 1995.

Nurcholish Madjid, Islam Kerakyatan dan keindonesiaan, Bandung: Mizan, 1994.

Rafa'al, M., \& Sangadji, S. S. (2020). MERAWAT MODERASI BERAGAMA CERDAS BERMEDIA DI PONDOK PESANTREN HARISUL KHAIRAAT KELURAHAN OME KOTA TIDORE KEPULAUAN. Jurnal Abdimas Bina Bangsa, I (2), 223-230.

Robert Hagedorn, (ed.), Essentials of Sociology. Canada: Holt, Rinehart and Winston of Canada, Limited Toronto, 198I.

Roland Robertson, (ed.), Agama Dalam Analisa dan Intrpretasi Sosiologis. Terj. Achmad Fedyani Saifuddin, Jakarta: PT. Raja Grafindo Persada, 1995.

Standar Akuntansi Keuangan tentang Laporan Keuangan Pesantren (2018). 